\title{
Replication of segment-specific and intercalated cells in the mouse renal collecting system
}

\author{
Philipp Wehrli • Dominique Loffing-Cueni • \\ Brigitte Kaissling • Johannes Loffing
}

Accepted: 29 November 2006 / Published online: 22 December 2006

(C) Springer-Verlag 2006

\begin{abstract}
The renal collecting system (CS) is composed of segment-specific (SS) and intercalated (IC) cells. The latter comprise at least two subtypes (type A and non-type A IC). The origin and maintenance of cellular heterogeneity in the CS is unclear. Among other hypotheses, it was proposed that one subtype of IC cells represents a stem cell population from which all cell types in the CS may arise. In the present study, we tested this stem cell hypothesis for the adult kidney by assessing DNA synthesis as a marker for cell replication. SS and IC cells were identified by their characteristic expressions of sodium- (epithelial sodium channel, Na-K-ATPase), water- (aquaporin-2) and acid/base- $\left(\mathrm{H}^{+}\right.$-ATPase, anion exchanger AE1) transporting proteins. Immunostaining for bromodeoxyuridine (BrdU) and for the proliferating cell nuclear antigen (PCNA) was used to reveal DNA synthesis in CS epithelium. BrdU- and PCNA-immunostaining as well as mitotic figures were seen in all subtypes of CS cells. Dividing cells retained the cell-type specific expression of marker molecules. Treatment of mice with bumetanide combined with a high oral salt intake, which increases the tubular salt load in the CS, profoundly increased the DNA-synthesis rate in SS and non-type A IC cells, but reduced it in type A IC cells.
\end{abstract}

\footnotetext{
P. Wehrli $\cdot$ B. Kaissling

Institute of Anatomy,

University of Zurich, Zurich, Switzerland

D. Loffing-Cueni $\cdot$ J. Loffing $(\square)$

Department of Medicine, Unit of Anatomy,

University of Fribourg, Route Albert Gockel 1,

1700 Fribourg, Switzerland

e-mail: johannes.loffing@unifr.ch
}

Thus, our data show that DNA synthesis and cell replication occur in each cell lineage of the CS and in differentiated cells. The replication rate in each cell type can be differently modulated by functional stimulation. Independent proliferation of each cell lineage might contribute to maintain the cellular heterogeneity of the CS of the adult kidney and may also add to the adaptation of the CS to altered functional requirements.

Keywords Principal cells $\cdot$ Intercalated cells · Differentiation $\cdot \mathrm{H}^{+}$-ATPase $\cdot \mathrm{ENaC}$

\section{Introduction}

The epithelium of the renal collecting system (CS), i.e., the connecting tubule (CNT) and the collecting duct (CD), is formed by a heterogeneous cell population comprising segment-specific (SS) CNT, CD cells ${ }^{1}$ and intercalated (IC) cells (Brown and Breton 1996; Kim et al. 1999; Wagner et al. 2004). SS cells control the fine tuning of renal $\mathrm{Na}^{+}, \mathrm{K}^{+}$and water excretion via specific apical $\mathrm{Na}^{+}$(i.e., the epithelial sodium channel, $\mathrm{ENaC}$ ), $\mathrm{K}^{+}$and water (i.e., aquaporin-2, AQP2) channels, while IC cells are mainly involved in the renal control of acid-base homeostasis. The IC cells are further subdivided into at least two subtypes (type $\mathrm{A}$ and type $\mathrm{B}$ ) that differ morphologically and functionally (Brown and Breton 1996; Kim et al. 1999; Wagner et al. 2004). Type A IC cells secrete protons into the urine via a vacuolar $\mathrm{H}^{+}$-ATPase in the apical plasma membrane and transport $\mathrm{HCO}_{3}^{-}$in exchange for $\mathrm{Cl}^{-}$into the

\footnotetext{
${ }^{1}$ The segment-specific cells of the collecting duct are also termed principal cells.
} 
peritubular interstitium via a basolateral band 3 like $\mathrm{Cl}^{-} / \mathrm{HCO}_{3}^{-}$anion exchanger (AE1) (Drenckhahn et al. 1985; Brown et al. 1988; Alper et al. 1989). Type B IC cells exhibit a functional polarity that is inverse to that of type A IC cells. Protons are transported into the peritubular interstitium across the basolateral plasma membrane via the $\mathrm{H}^{+}$-ATPase, while bicarbonate is secreted into the urine by an apical $\mathrm{Cl}^{-} / \mathrm{HCO}_{3}^{-}$ exchanger that is likely pendrin (Royaux et al. 2001; Wall et al. 2003; Wagner et al. 2004). A third type of IC cells (non-A, non-B IC), which is AE1-negative and co-expresses pendrin and $\mathrm{H}^{+}$-ATPase in the apical plasma membrane, was described (Teng-umnuay et al. 1996; Kim et al. 1999; Wall et al. 2003), but the physiological function of this cell-type is unclear and it is conceivable that these cells represent modified subtypes of type B IC cells. For the sake of simplicity, we will distinguish in the following only between AE1-positive type A IC and AE1-negative non-type A IC.

Several studies aimed to identify the origin of the cellular heterogeneity of the renal CS (e.g., Satlin and Schwartz 1987; Minuth et al. 1989; Fejes-Toth and Naray-Fejes-Toth 1992; Satlin et al. 1992; Yasoshima et al. 1992; Kim et al. 1994, 1996; Verlander et al. 1994; Matsumoto et al. 1996; Kloth et al. 1998; Schwartz 2001). Based on the morphological studies on developing rat kidneys, Madsen et al. concluded that type A and non-type A IC cells develop independently from undifferentiated cells in the CNT and the medullary CD (Kim et al. 1994). However, Brown et al. (1988, 1996) observed in the developing CDs of rats, constantly few cells that express both the water channel AQP2 (an SS cell marker) and AE1, suggesting that SS and IC cells may arise from a common ancestor with SS and IC characteristics (Sabolic et al. 1995). Consistent with this hypothesis, recent studies on mice with targeted inactivation of the forkhead transcription factor Foxi1 revealed an impaired terminal differentiation of the renal CS with a CS lined by a homogeneous cell population co-expressing both SS and IC marker molecules (Blomqvist et al. 2004).

The phenomenon of marked epithelium heterogeneity is relevant also to the CS of adult kidneys. Renal epithelia are constantly renewed by a low basal level of cell proliferation. Cell division may even rise to very high levels following ischemic (Witzgall et al. 1994) or toxic tubular injury (Nouwen et al. 1994) as well as during renal adaptive growth after extensive ablation of renal mass (Norman et al. 1988) or increased tubular ion transport activity (Loffing et al. 1995). It remains unclear how the cellular heterogeneity in the CS is maintained under these conditions. Are all cell types in the CS capable of cell proliferation or is cell replication limited to a certain subtype of epithelial cells, which then transform into other cell lineages? Indeed, previous in vitro studies suggested that type B IC cells may represent a stem cell population that gives rise to all cell subtypes in the CS (Fejes-Toth and Naray-FejesToth 1992). Moreover, there exists some uncertainty about the degree of cellular differentiation of dividing cells in the kidney and it is often assumed that cell division is limited to less differentiated precursor cells (i.e., stem cells and transit amplifying cells) that do not reach the same structural, molecular and antigenic characteristics as that of their terminally differentiated progeny (Alison et al. 2002; Anglani et al. 2004).

In our present study, we tested the hypothesis that cell replication occurs in all cell subtypes of the CS of the adult healthy kidney and in differentiated epithelial cells. To reach these ends, we assessed DNA synthesis in the SS and IC cells in the renal cortical CS (i.e., CNT and CCD cells). SS CNT and CCD cells as well as IC cells (type $\mathrm{A}$ and non-type $\mathrm{A}$ ) were identified on account of the expression of specific marker molecules. The DNA synthesis rate for each cell type was determined by immunostaining of the proliferating cell nuclear antigen (PCNA), a cofactor for DNA-polymerase delta, and of the thymidine analogue, bromodeoxyuridine (BrdU), that was incorporated in replicating DNA during its application period (Dietrich 1993; Iatropoulos and Williams 1996). Our data reveal that in adult mice, all three cell types of the CS can replicate DNA. Moreover, we found that the DNA synthesis rate is differentially regulated between the different cellular subtypes in response to changes in the tubular $\mathrm{NaCl}$ load. Cell replication originates from fully differentiated cells, which show the same expression pattern of cell-type specific membrane proteins as their non-dividing counterparts.

\section{Methods}

\section{Experimental protocol}

The experiments were performed on ten male NMRI mice (BRL, Füllinsdorf, $\mathrm{CH}$ ) of 8 weeks and of $30 \pm 2$ g body weight. The mice were randomly divided into two groups of five mice each that received either vehicle or bumetanide. All mice were housed individually in standard cages with free access to standard lab chow and two bottles of drinking solutions. One bottle contained tap water and the other contained a salt solution $(0.8 \% \mathrm{NaCl}+0.1 \% \mathrm{KCl})$. All mice received BrdU (40 mg/kg per day), which was continuously applied via osmotic minipumps (model 1003D; Alza Corp., Palo 
Alto, CA, USA) implanted subcutaneously in the neck region under light anesthesia with Methoxyflurane (Metofane $^{\circledR}$; Mallinckrodt Vet. Inc., Mundelein, IL, USA). The BrdU was dissolved in a 3:1 solution of polyethylene glycol 300 (PEG 300; Fluka Chemie, Buchs, $\mathrm{CH}$ ) and distilled water. In bumetanide-treated mice, bumetanide (final dose: $40 \mathrm{mg} / \mathrm{kg}$ per day) was added to the BrdU solution. Prior to implantation, all osmotic minipumps were primed for $4 \mathrm{~h}$ in $37^{\circ} \mathrm{C}$ warm saline as recommended by the supplier. Simultaneously with the implantation of the minipump, the experimental animals received by subcutaneous injection a loading dose of bumetanide $(40 \mathrm{mg} / \mathrm{kg})$.

\section{Tissue fixation and processing}

The animals were anesthetized by intraperitoneal injection of $50 \mu \mathrm{l}$ of a 3:1 mixture of ketamine (Narke$\tan ^{\circledR} 10$; Chassot AG, Belp, CH) and xylazine (Rompun $^{\circledR} 2 \%$ solution of xylazinhydrochloride; Bayer AG, Leverkusen, D) $72 \pm 1 \mathrm{~h}$ after the implantation of the minipumps, and the kidneys were fixed by intravascular perfusion through the abdominal aorta. The fixative was $3 \%$ paraformaldehyde and $0.05 \%$ picric acid in a 6:4 mixture of $0.1 \mathrm{M}$ cacodylate buffer $(\mathrm{pH} 7.4$, adjusted to $300 \mathrm{mOsm}$ with sucrose) and $10 \%$ hydroxyethyl starch in saline (HAES steril ${ }^{\mathrm{TM}}$; Fresenius AG, D). The kidneys were removed, frozen in liquid propane, cooled with liquid nitrogen and stored at $-80^{\circ} \mathrm{C}$ until use. Cryosections ( $5 \mu \mathrm{m}$ thick) were placed on a chrome-alum gelatin-coated glass slide and processed for immunohistochemistry.

\section{Immunohistochemistry}

Monoclonal antibodies against BrdU (Becton-Dickinson, San Jose, CA, USA), PCNA (Dakopatts, Glostrup, DK), vacuolar $\mathrm{H}^{+}$-ATPase $\left[M_{\mathrm{r}}=31,000\right.$ subunit; (Hemken et al. 1992); provided by Dr Gluck] and polyclonal antibodies against anion exchanger AE1 [amino acids 917-929; (Ercolani et al. 1992); provided by Dr Alper], $\gamma \mathrm{ENaC}$ (Rubera et al. 2003; provided by Dr Rossier), Na-K-ATPase (Feraille et al. 1999; provided by Dr Feraille) and AQP2 (Alomone, Jerusalem, Israel) were used. Prior to the immunostaining, the sections were boiled in $0.01 \mathrm{M}$ sodium citrate buffer $(\mathrm{pH}$ 6.0) for $10 \mathrm{~min}$ in a microwave oven (Shi et al. 1991). For the detection of BrdU, the sections were additionally pretreated with sodium dodecyl sulfate (SDS, $0.1 \%$ ) for $2 \mathrm{~min}$ at room temperature, based on a protocol initially described by Brown et al. (1996).

Sections were pre-incubated with a $10 \%$ normal goat serum in PBS for 10 min. Afterwards, monoclonal antibodies against either BrdU (dilution 1/50) or PCNA (dilution 1/50) were applied for at least $12 \mathrm{~h}$ at $4^{\circ} \mathrm{C}$. Binding sites of the primary antibodies were revealed with a $\mathrm{Cy} 3^{\mathrm{TM}}$ - or FITC-labeled goat-antimouse-IgG antibodies (diluted 1:200 and 1:40, respectively). Thereafter, mouse monoclonal antibodies against $\mathrm{H}^{+}$-ATPase (diluted 1:2) and/or rabbit polyclonal antibodies against AE1 (diluted 1:750), $\gamma \mathrm{ENaC}$ (diluted 1:400), Na-K-ATPase (diluted 1:500) and AQP2 (diluted 1/500) were applied. The binding sites of these antibodies were detected by the use of FITClabeled goat-anti-mouse-IgG (diluted 1:40) and $\mathrm{Cy} 3^{\mathrm{TM}}$ labeled goat-anti-rabbit-IgG (diluted 1:1,000; all secondary antibodies from Jackson ImmunoResearch Lab. Inc., West Grove, PA, USA). Incubations with the fluorescence-conjugated secondary antibodies took place in a humidified chamber at room temperature for $1 \mathrm{~h}$. The cell nuclei were stained with 4,6-diamidino-2phenylindole dihydrochloride (DAPI; Boehringer, Mannheim, D). The slides were mounted in DAKOglycergel (Dakopatts) containing $2.5 \%$ of 1,4-diazabicyclo[2.2.2]-octane (DABCO; Sigma, St Louis, MO, USA) as a fading retardant. For control of unspecific binding of the antibodies, we performed incubations with non-immune sera or by omitting the primary antibody. All control experiments were negative. In some experiments, apoptotic cells were revealed by the use of the TUNEL (terminal deoxynucleotidyl transferase mediated dUTP Nick End Labeling) method (Apop$\mathrm{Tag}^{\circledR}$; Chemicon; VWR International Dietikon, Switzerland), which specifically labels the $3^{\prime}-\mathrm{OH}$ blunted ends of the fragmented DNA. The kit was used as recommended by the supplier.

\section{Evaluation of immunofluorescence}

The sections were studied by epifluorescence (Polyvar microscope; Reichert Jung, Vienna, A), images were acquired with a Visicam CCD camera (Visitron Systems, Puching, D) and processed by Image-Pro ${ }^{\circledR}$ and Photoshop ${ }^{\circledR}$ software. IC and SS cells were identified according to previously described criteria (Alper et al. 1989). Type A IC cells were recognized by immunofluorescent staining at the basolateral plasma membrane for AE1, and for $\mathrm{H}^{+}$-ATPase at the apical plasma membrane and/or in the apical cytoplasm. Non-type A IC cells were AE1-negative and exhibited a strong immunofluorescence for the $\mathrm{H}^{+}$-ATPase in the apical and/or basolateral cytoplasma or within the whole cytoplasm. The SS cells were AE1-negative, revealed only occasionally (in the CNT) weak staining with the antibody against $\mathrm{H}^{+}$-ATPase (Alper et al. 1989) and were characterized by strong $\gamma \mathrm{ENaC}, \mathrm{Na}-\mathrm{K}-\mathrm{ATPase}$ and AQP2 
immunostaining. BrdU- or PCNA-positive nuclei were usually stained by both of the applied FITC- and Cy3conjugated anti-mouse monoclonal antibodies.

\section{Quantitative evaluations}

The fraction of SS and IC (type A and non-type A) cells in the epithelium of the CS was determined by counting the cell nuclei. Chromatin staining was made with DAPI. Tubular profiles of the CS were randomly selected and the number of SS, type A and non-type A cell nuclei versus the total number of nuclei (at least 1,000 per segment) within the profile were determined. The DNAsynthesis rates were determined by the labeling index (LI; labeled cells per 100 cells) for BrdU and PCNA, respectively. At least 500 cells per cell type (A-ICc, B-ICc and SSc) and per animal were counted. Five and three mice per group were analyzed for BrdU-LI and PCNA-LI, respectively. Quantitation did not distinguish between CNT and CCD segments. Thus, data reflect the LI for the respective cell types in the entire renal cortical CS to which the CNT and CCD contribute about twothirds and one-third, respectively (Loffing et al. 2004).

\section{Statistics}

Data are given as mean \pm SEM. Statistical differences between two groups were evaluated by the Student's $t$-test using standard computer software. Differences were considered to be significant when $P<0.05$.

\section{Results}

Effect of bumetanide treatment and high $\mathrm{NaCl}$ intake on body weight and fluid intake

As previously reported for rats (Loffing et al. 1995), implantation of osmotic minipumps and continuous BrdU application did not cause any clinical signs of illness. The body weight slightly increased in vehicletreated rats but decreased significantly in bumetanidetreated rats (Table 1). This bumetanide-induced loss of body weight is likely explained by the potent diuretic effect of loop diuretics for which the mice apparently could not fully compensate by a high oral intake of tap water and salt solution (Table 1).

DNA synthesis occurs in SS cells, type A and non-type A IC cells

Up-regulation of PCNA in cell nuclei reveals that the cell progresses in the cell cycle. Nuclear PCNA
Table 1 Change of body weight and fluid intake during the last $24 \mathrm{~h}$ of either vehicle or bumetanide treatment

\begin{tabular}{llll}
\hline Group & $\begin{array}{l}\text { Change of body } \\
\text { weight }(\mathrm{g} / 24 \mathrm{~h})\end{array}$ & \multicolumn{2}{l}{ Fluid intake $(\mathrm{ml} / 24 \mathrm{~h})$} \\
\cline { 3 - 4 } & & $\begin{array}{l}\text { Tap } \\
\text { water }\end{array}$ & $\begin{array}{l}\text { Salt } \\
\text { solution }\end{array}$ \\
\hline Vehicle & $0.4 \pm 0.1$ & $5.3 \pm 0.5$ & $3.0 \pm 0.5$ \\
Bumetanide & $-1.2 \pm 0.2^{*}$ & $14.2 \pm 2.0^{*}$ & $17.1 \pm 3.4^{*}$ \\
\hline
\end{tabular}

Data are mean \pm SEM, $n=5$ per group

*Differences between groups are statistically significant $(P>0.05)$

expression becomes detectable in late G1, reaches very high levels during transition from $\mathrm{G} 1$ to $\mathrm{S}$, declines during late $S$ and returns to undetectable levels after mitosis (Dietrich 1993). As in previous studies (Loffing et al. 1995), only nuclei that displayed an intense nuclear staining pattern were considered as being in the early S-phase and counted in the quantitative evaluation. The majority of tubular cells were unstained. A subportion of cells revealed weak to very strong immunostainings. Strong PCNA staining was seen in SS, type A and non-type A IC cells. IC cell subtypes were identified and distinguished from SS cells on account of their typical binding of antibodies against $\mathrm{H}^{+}$-ATPase and AE1 (Alper et al. 1989) (Fig. 1).

BrdU is incorporated into the DNA synthesized during the period of BrdU application and can be detected using anti-BrdU antibodies. The immunodetection requires antigen retrieval. Treatment of the tissue sections with microwave and SDS-denaturation yielded a strong labeling of a subset of nuclei with antiBrdU antibodies (Fig. 1), without any staining of other tissue components and without apparent damage of the tissue structure. Cells in various phases of mitosis were apparent due to BrdU staining of chromosomes (Fig. 2). Immunostaining for BrdU in nuclei as well as in mitotic figures was detected in SS, type A, and nontype A IC cells of the CS. This is evidence that all the three cell types are capable of DNA synthesis and cell division (Figs. 1, 2).

Remarkably, replicating cells revealed the same characteristic expression and subcellular localization of membrane proteins as their neighboring non-dividing IC and SS cells, as evident by co-immunostainings of PCNA with $\mathrm{H}^{+}$-ATPase and AE1 (Fig. 1) and coimmunostainings of PCNA with $\gamma \mathrm{ENaC}, \mathrm{Na}-\mathrm{K}$ ATPase and AQP2 (Fig. 3). Figures 1, 2 and 3 show CNT profiles. Similar findings were made for CCD. Thus, cell replication was similarly observed in SS and IC cell types of both CNT and CCD segments. We did not specifically analyze cell replication of IC cells in the late distal convoluted tubule, which usually does also 

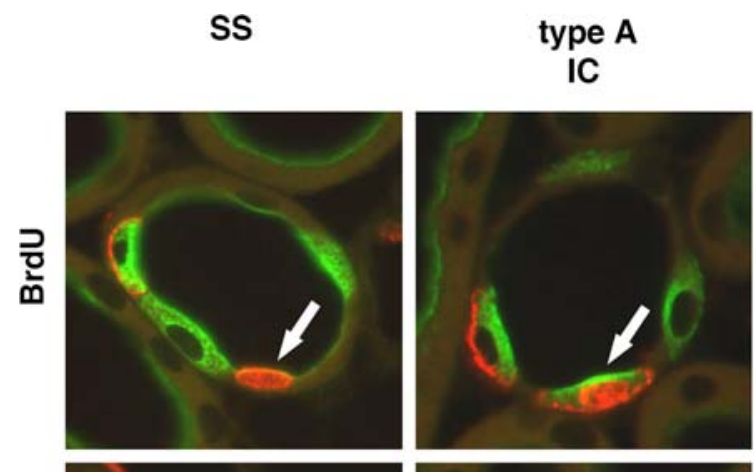

non-type A
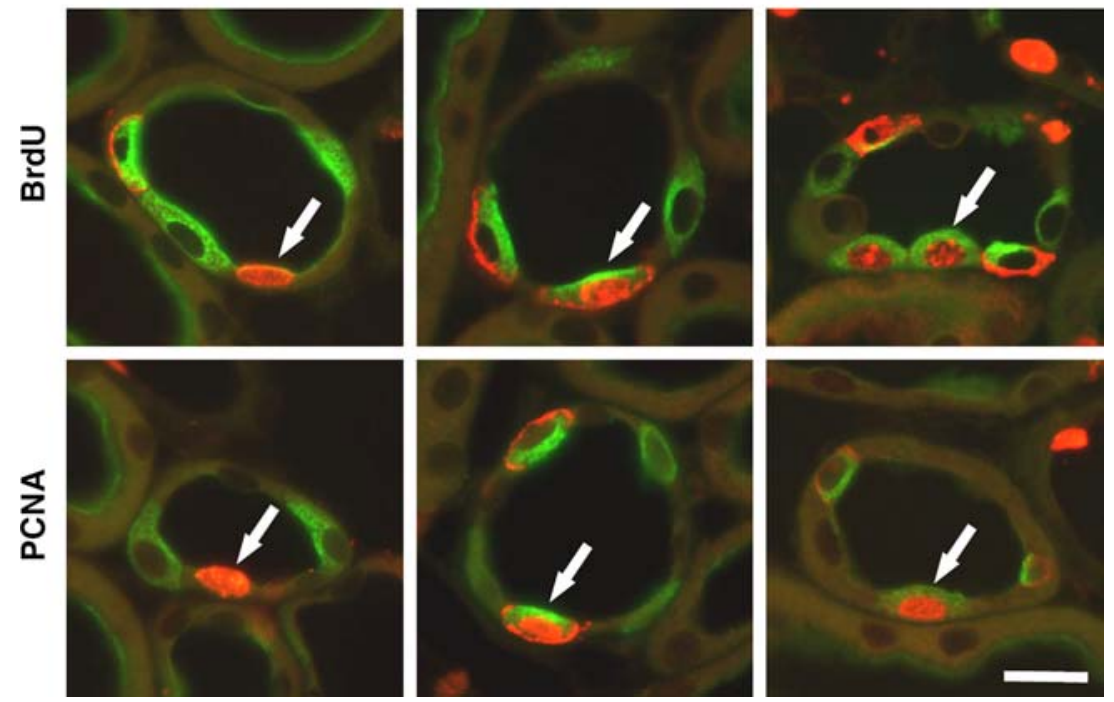

Fig. 1 Immunostainings for BrdU (upper panel) and PCNA (lower panel) combined with immunostaining for $\mathrm{H}^{+}$-ATPase (green fluorescence) and AE1 (red fluorescence) on cryostat sections of kidneys from control mice. PCNA- and BrdU-positive cell nuclei (in red) are visible in segment-specific (SS) CNT cells and in type A and non-type A intercalated (IC) cells. Type A IC cells display $\mathrm{H}^{+}$-ATPase labeling in the apical plasma membrane and AE1 in the basolateral plasma membrane, while non-type A IC cells are AE1-negative and display $\mathrm{H}^{+}$-ATPase in the cytoplasm. SS cells are $\mathrm{H}^{+}$-ATPase and AE1-negative. Bar $\sim 10 \mu \mathrm{m}$

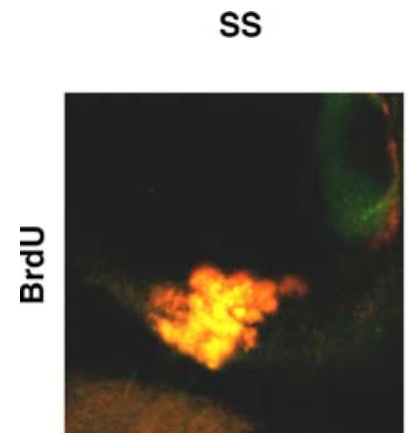

Fig. 2 Mitotic figures in segment-specific (SS) CNT cells, in type $\mathrm{A}$ and non-type A intercalated (IC) cells of control mice. Immunofluorescence on cryostat sections for $\mathrm{BrdU}($ red $)$, and $\mathrm{H}^{+}$-ATPase (green) and AE1 (red); chromosomes are BrdU-labeled, the

contain few IC cells (Kim et al. 1999), but we have no evidence to believe that IC cells at this site behave differently from IC cells in the CS.

DNA-synthesis rates are different in the three studied cell types

Because all cell types in the CS are capable of DNA synthesis, we wondered whether the DNA-synthesis rate of the three cell types might be differentially regulated. To address this question, we took advantage of a previously well-characterized experimental model in which enhanced tubular salt load affects cell growth in the CS (Kaissling and Stanton 1988; Ellison et al.

\section{non-type A}

IC

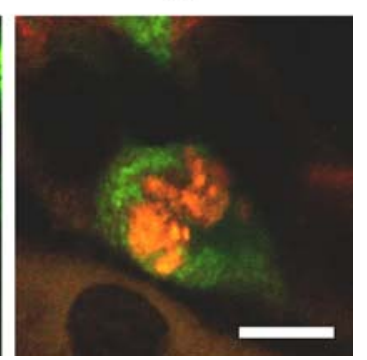

type A IC displays $\mathrm{H}^{+}$-ATPase labeling in the apical plasma membrane and AE1 in the basolateral plasma membrane; the non-type A IC is AE1-negative and displays $\mathrm{H}^{+}$-ATPase in the cytoplasm. The SS cell is $\mathrm{H}^{+}$-ATPase and AE1-negative. Bar $\sim 5 \mu \mathrm{m}$

1989). In this model, treatment with loop diuretics combined with a high dietary $\mathrm{NaCl}$ intake drastically increases the salt delivery to the renal CS. Both, SS (Kaissling and Stanton 1988; Ellison et al. 1989) and type B IC (Kim et al. 1992) cells respond to this enhanced tubular salt load by cellular hypertrophy while the type A IC cells reveal reduction in cell size (Kim et al. 1992). We analyzed now whether bumetanide and high oral salt provokes corresponding effects on cellular DNA synthesis in the CS, and thus cell proliferation. Therefore, we determined the LI for BrdU and PCNA, respectively (see Methods) for each of the three cell types. Both methods demonstrated that DNA synthesis is indeed differently modulated in the 
Fig. 3 Immunostainings for PCNA (shown in red) and $\gamma \mathrm{ENaC}, \mathrm{Na}-\mathrm{K}$-ATPase and AQP2 (shown in green) on cryostat sections of kidneys from control mice. CNT profiles are shown. Similar observations are made in CCD (not shown). PCNA-positive SS cells exhibit a similar expression and subcellular distribution of $\gamma \mathrm{ENaC}, \mathrm{Na}-\mathrm{K}-$

ATPase and AQP2 as PCNAnegative SS cells. IC cells are not stained with the anti- $\gamma \mathrm{ENaC}, \mathrm{Na}-\mathrm{K}$-ATPase and AQP2 antibodies. Bar $\sim 10 \mu \mathrm{m}$
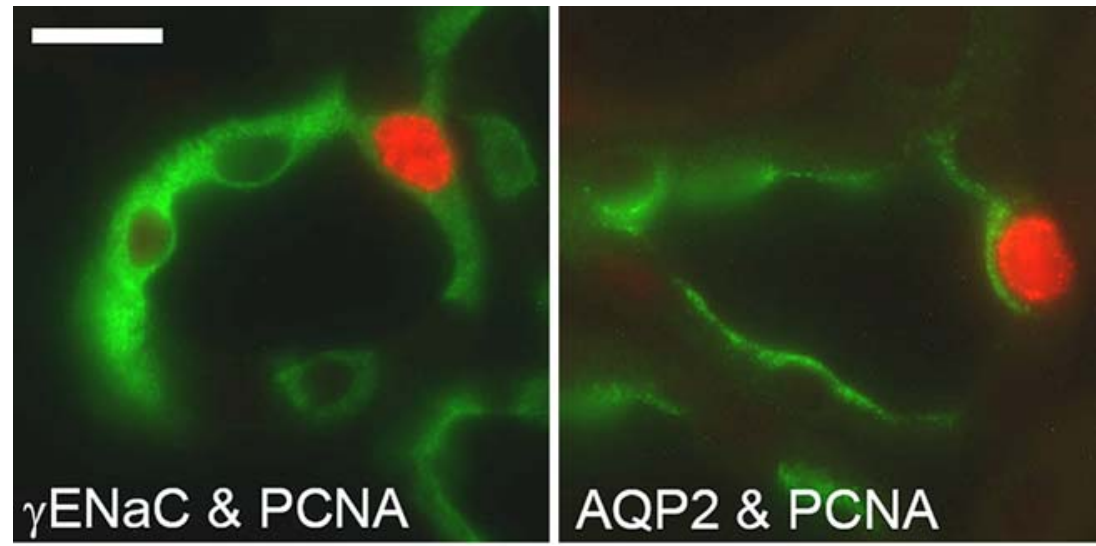

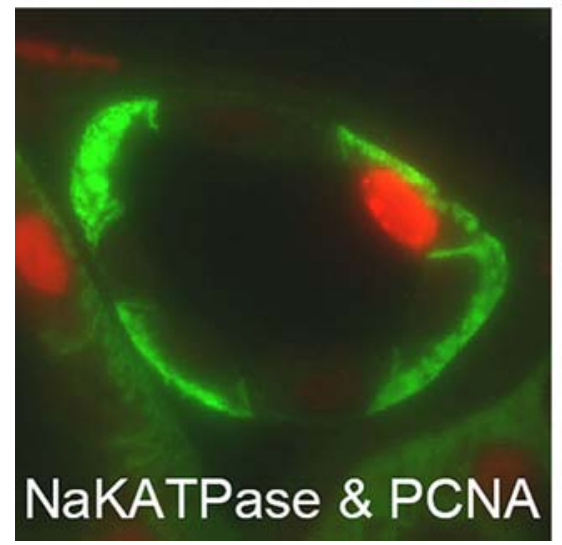

three cell types in response to bumetanide treatment and salt loading (Fig. 4). Although PCNA and BrdU immunostaining gave qualitatively identical results, the BrdU-LI was higher than the PCNA-LI. This is explained by the fact that incorporated BrdU is detectable in the progeny of dividing cells, and thus, the number of positive cells and the BrdU-LI, necessarily increases with time in a cycling cell population. In contrast, PCNA depicts only those cells that are in S-phase at the time of sacrifice of the animal.

The ratio of the different cell types is not profoundly altered by the treatment

In order to see whether the altered DNA synthesis affected the ratio of the different cell types in the CS epithelium, we quantified the percentage of cell types in the CS of vehicle and bumetanide-treated mice (Fig. 5). The differences between groups were rather minor. While in the bumetanide group the relative number of SS cells was unaffected compared to vehicle, that of type A IC cells was slightly decreased, and that of nontype A IC cells was slightly increased. The rather constant fractional abundance of the different cell types suggests that the altered DNA synthesis rate reflects differences in cell turnover. Therefore we examined whether, for example, tubular cell death might be enhanced. However, we found no histological evidence for tubular cell damage and the TUNEL method did not reveal any apoptotic cell nuclei in kidneys of vehicle- or bumetanide-treated mice. Kidneys from thiazide-treated rats, which served as positive control, however, revealed numerous apoptotic cell nuclei in distal tubule cells, as previously reported (Loffing et al. 1996). It is possible that in the analyzed mice, dying cells were rapidly removed from the epithelium, for example by shedding into the tubular lumen (Kim et al. 1996), and therefore escaped the detection by standard histology and the TUNEL method.

\section{Discussion}

DNA synthesis is a prerequisite for cell proliferation. In previous studies, we showed by using the immunohistochemical detection of the PCNA and of BrdU incorporated in DNA that DNA synthesis occurs in adult healthy rats in all analysed tubular segments, though at different rates (Loffing et al. 1995). While proximal tubules, thick ascending limbs (TALs) and most parts of the distal convoluted tubule are each lined by a homogenous cell population, the segments of the CS, the CNT and CD, are composed by SS cells and IC cells. The proliferation kinetics of these differ- 

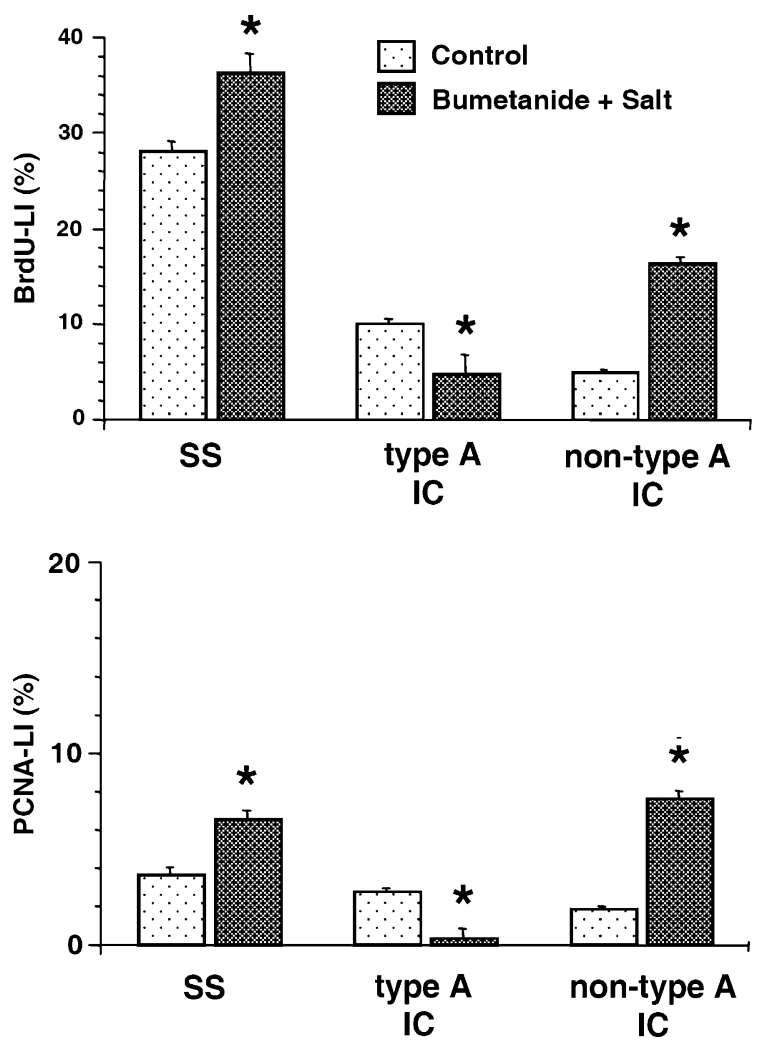

Fig. 4 BrdU labeling index (upper panel) and PCNA labeling index (lower panel) in SS-, type A IC and non-type A IC cells of untreated and bumetanide-salt treated mice. BrdU was applied continuously over 3 days. Therefore, the BrdU-labeled fraction of cells comprises the entire population of cells that underwent DNA synthesis during these 3 days of BrdU treatment and is thus higher than the PCNA-labeled fraction that comprises only those cells, which were in the S-phase of the cell cycle at the moment of killing the animals. Both CNT and CCD segments were included in the analysis. Data mean $\pm \mathrm{SEM}, n=5$ per group for BrdU and $n=3$ per group for PCNA, $* P<0.05$ versus control

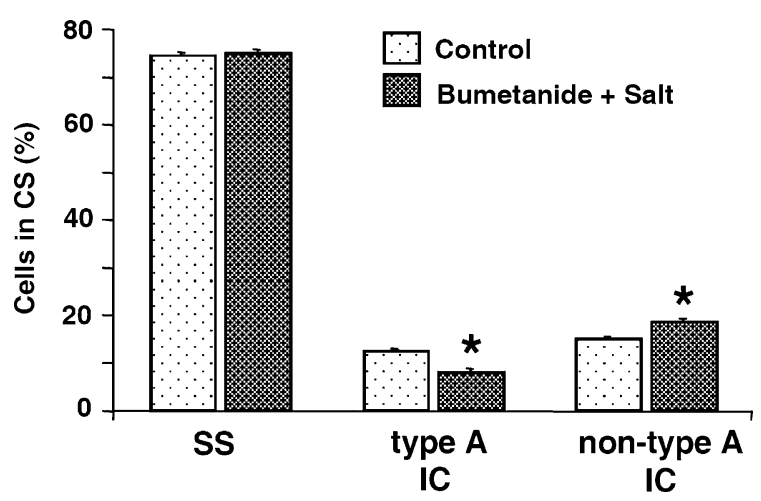

Fig. 5 Fractions of SS-, type A IC and non-type A IC cells in the collecting system of control and bumetanide salt-treated mice. Both CNT and CCD segments were included in the analysis. Data mean $\pm \mathrm{SEM}, n=5$ per group, $* P<0.05$ versus control

ent cell types was not specifically addressed in our previous studies (Loffing et al. 1995). It remained unresolved whether all or only a particular cell type within the cortical CS are/is capable of proliferation. By detection of cell-type specific marker molecules, we now clearly show DNA synthesis and mitosis in all analysed cell types of the CS. Remarkably, the cycling cells apparently retain their specific expression of marker molecules (ENaC and AQP2 for SS cells; $\mathrm{H}^{+}$-ATPase and/or AE1 for IC cells) during cell replication. Likewise, Vogetseder et al. (2005) reported recently that dividing proximal and distal convoluted tubule cells maintain the expression of specific marker molecules and display a similar level of differentiation as non-dividing neighbouring cells supporting the idea that epithelial cell renewing in the healthy kidney originates from differentiated tubular cells.

Based on the observation that during kidney development the fraction of SS decreases in the CD while the fraction of IC increases, Kim et al. (1994) concluded that IC cells proliferate more rapidly than SS cells. However, in the present study on adult mice we found higher proliferation rates in SS than IC cells. Among the latter, the non-type A cells proliferated more than type A IC. The physiological meaning of these distinct differences in cell replication rate are unclear, but the rather fixed ratio of SS, and type A and non-type A IC cells in the normal, adult kidney suggests that the pronounced variations in cell replication likely reflect differences in cell-turnover. It is remarkable that more than $27 \%$ of the SS cells incorporated BrdU within 3 days of BrdU application and were hence, renewed by cell proliferation during this short period of time. In rats, we previously determined under similar experimental conditions a BrdU-LI of about $7 \%$ for all SS cells (Loffing et al. 1995). Because the age and sex of the analyzed mice and rats were similar, these quantitative differences may reflect clear species differences.

DNA synthesis and hence cell proliferation may not only vary between cell types but also in response to functional stimulation. In fact, we previously showed a close link between ion transport rates of a particular epithelium and its DNA synthesis rate (Loffing et al. 1995). The same link can be assumed for our present experiments. Three days of bumetanide treatment combined with a high salt intake stimulated DNA synthesis in SS and non-type A IC while it decreased DNA synthesis in type A IC cells. These differential effects on DNA synthesis are consistent with pervious morphological observations which suggested increased transport activity in SS and non-type A IC but reduced ion transport in type A IC under chronic loop-diuretic treatment combined with high salt intake (Kaissling and Stanton 1988; Stanton and Kaissling 1988; Ellison et al. 1989; Kim et al. 1992). 
Our study used bumetanide and high oral salt intake as a tool to modulate DNA synthesis. We did not aim to analyze the underlying mechanism and we can only speculate about them. Direct effects of bumetanide on the CS are unlikely, since loop diuretics specifically inhibit salt transport in the TAL. However, transport inhibition in TAL provokes a variety of secondary effects, which impact on ion transport in the renal CS. Together with the high oral salt intake, it increases the salt delivery to the CS, which is thought to stimulate $\mathrm{Na}^{+}$reabsorption via the apical sodium channel ENaC in SS cells ( $\mathrm{Na}$ et al. 2003) and $\mathrm{Cl}^{-}$reabsorption via apical pendrin in the non-type A IC cells (Quentin et al. 2004). Diuresis-induced extracellular volume contraction with hyperaldosteronemia may also contribute to the activation of ion transport and DNA synthesis in SS and non-type A IC cells. Aldosterone is known to stimulate ENaC activity in SS cells (Verrey et al. 2003) and was also suggested to regulate pendrin expression in non-type A IC cells (Verlander et al. 2003). Moreover, loop-diuretic treatment is frequently associated with metabolic alkalosis (Eiam-Ong et al. 1993; Loffing et al. 1995; van de Ven et al. 1999) which stimulates the bicarbonate-secreting non-type A IC cells but suppresses the activity of acid-secreting type A IC cells.

Given the pronounced and differential effects of bumetanide on the DNA synthesis rate of SS cells (PCNA-LI $180 \%$ of control), non-type A IC cells (PCNA-LI $440 \%$ of control) and type A IC cells (PCNA-LI 13\% of control), it is surprising that the relative abundance of these different cell types was not (SS cells) or only slightly (type A and non-type A IC cells) affected by the bumetanide treatment. This suggests that the differential regulation of DNA synthesis within the different subpopulations of CS cells does not lead to a major remodeling of the cellular composition of the renal CS. Perhaps it more likely reflects a different cell turnover rate. It is conceivable that transporting epithelial cells may age faster and have to be more rapidly renewed than epithelial cells with low transport activity. Recently, Christensen et al. (2006) reported a pronounced remodeling of the medullary CDs of lithium-treated rats leading to an increased fraction of IC cells and a reduced fraction of prinicipal cells in the CD. Interestingly, this severe epithelial remodeling was accompanied mainly by enhanced proliferation of principal and not IC cells. Thus, enhanced cell proliferation in one particular cell lineage need not necessarily lead to a congenerous shift in the fractional contribution of one cell type to a heterogeneous cell population. Whether altered cell proliferation rates may contribute to the cellular remodeling of the CS epithelium during changes in systemic acid/base homeostasis
(Yasoshima et al. 1992; Tsuruoka and Schwartz 1996) or during carbonic anhydrase inhibition (Bagnis et al. 2001) remains to be analyzed. Some studies (FejesToth and Naray-Fejes-Toth 1992; Yasoshima et al. 1992; Schwartz et al. 2002) did also suggest that some changes in the prevalence of a particular IC cell subtype might be related to the conversion of one cell type to the other (e.g., from type A IC cells to non-type A IC cells).

In summary, our study provides evidence that all subtypes of cells within the adult renal CS are capable of cell proliferation. Independent replication of each cell subtype may help to maintain the cellular heterogeneity of the renal CS and may also contribute to the functional adaptation of the epithelium to altered ion transport requirements.

Acknowledgments Antibodies against $\mathrm{H}^{+}$-ATPase, AE1, $\gamma \mathrm{ENaC}$ and Na-K-ATPase were kindly provided by Drs S. Gluck, S. Alper, B. Rossier and E. Feraille, respectively. We thank Drs S. Alper, D. Eladari, M. Le Hir and C. Wagner for their comments on the manuscript. This work was supported by the Swiss National Science Foundation (3200B0-105769/1). The work is part of the M.D.-thesis of P. Wehrli.

\section{References}

Alison MR, Poulsom R, Forbes S, Wright NA (2002) An introduction to stem cells. J Pathol 197:419-423

Alper SL, Natale J, Gluck S, Lodish HF, Brown D (1989) Subtypes of intercalated cells in rat kidney collecting duct defined by antibodies against erythroid band 3 and renal vacuolar $\mathrm{H}^{+}$-ATPase. Proc Natl Acad Sci USA 86:5429-5433

Anglani F, Forino M, Del Prete D, Tosetto E, Torregrossa R, D'Angelo A (2004) In search of adult renal stem cells. J Cell Mol Med 8:474-487

Bagnis C, Marshansky V, Breton S, Brown D (2001) Remodeling the cellular profile of collecting ducts by chronic carbonic anhydrase inhibition. Am J Physiol Renal Physiol 280:F437F448

Blomqvist SR, Vidarsson H, Fitzgerald S, Johansson BR, Ollerstam A, Brown R, Persson AE, Bergstrom GG, Enerback S (2004) Distal renal tubular acidosis in mice that lack the forkhead transcription factor Foxi1. J Clin Invest 113:1560-1570

Brown D, Breton S (1996) Mitochondria-rich, proton-secreting epithelial cells. J Exp Biol 199:2345-2358

Brown D, Hirsch S, Gluck S (1988) An $\mathrm{H}^{+}$-ATPase in opposite plasma membrane domains in kidney epithelial cell subpopulations. Nature 331:622-624

Brown D, Lydon J, McLaughlin M, Stuart-Tilley A, Tyszkowski $\mathrm{R}$, Alper S (1996) Antigen retrieval in cryostat tissue sections and cultured cells by treatment with sodium dodecyl sulfate (SDS). Histochem Cell Biol 105:261-267

Christensen BM, Kim YH, Kwon TH, Nielsen S (2006) Lithiumtreatment induces a marked proliferation of primarily principal cells in rat kidney inner medullary collecting duct. Am J Physiol Renal Physiol 291:F39-F48

Dietrich DR (1993) Toxicological and pathological applications of proliferating cell nuclear antigen (PCNA), a novel endogenous marker for cell proliferation. Crit Rev Toxicol 23:77-109 
Drenckhahn D, Schluter K, Allen DP, Bennett V (1985) Colocalization of band 3 with ankyrin and spectrin at the basal membrane of intercalated cells in the rat kidney. Science 230:1287-1289

Eiam-Ong S, Kurtzman NA, Sabatini S (1993) Effect of furosemide-induced hypokalemic metabolic alkalosis on renal transport enzymes. Kidney Int 43:1015-1020

Ellison DH, Velazquez H, Wright FS (1989) Adaptation of the distal convoluted tubule of the rat. Structural and functional effects of dietary salt intake and chronic diuretic infusion. $\mathrm{J}$ Clin Invest 83:113-126

Ercolani L, Brown D, Stuart-Tilley A, Alper SL (1992) Colocalization of GAPDH and band 3 (AE1) proteins in rat erythrocytes and kidney intercalated cell membranes. Am J Physiol 262:F892-F896

Fejes-Toth G, Naray-Fejes-Toth A (1992) Differentiation of renal beta-intercalated cells to alpha-intercalated and principal cells in culture. Proc Natl Acad Sci USA 89:5487-5491

Feraille E, Carranza ML, Gonin S, Beguin P, Pedemonte C, Rousselot M, Caverzasio J, Geering K, Martin PY, Favre H (1999) Insulin-induced stimulation of $\mathrm{Na}^{+}$, K(+)-ATPase activity in kidney proximal tubule cells depends on phosphorylation of the alpha-subunit at Tyr-10. Mol Biol Cell 10:2847-2859

Hemken P, Guo XL, Wang ZQ, Zhang K, Gluck S (1992) Immunologic evidence that vacuolar $\mathrm{H}^{+}$-ATPases with heterogeneous forms of $\mathrm{Mr}=31,000$ subunit have different membrane distributions in mammalian kidney. J Biol Chem 267:9948-9957

Iatropoulos MJ, Williams GM (1996) Proliferation markers. Exp Toxicol Pathol 48:175-181

Kaissling B, Stanton BA (1988) Adaptation of distal tubule and collecting duct to increased sodium delivery. I. Ultrastructure. Am J Physiol 255:F1256-F1268

Kim J, Welch WJ, Cannon JK, Tisher CC, Madsen KM (1992) Immunocytochemical response of type $\mathrm{A}$ and type $\mathrm{B}$ intercalated cells to increased sodium chloride delivery. Am J Physiol 262:F288-F302

Kim J, Tisher CC, Madsen KM (1994) Differentiation of intercalated cells in developing rat kidney: an immunohistochemical study. Am J Physiol 266:F977-F990

Kim J, Cha JH, Tisher CC, Madsen KM (1996) Role of apoptotic and non-apoptotic cell death in removal of intercalated cells from developing rat kidney. Am J Physiol 270:F575-F592

Kim J, Kim YH, Cha JH, Tisher CC, Madsen KM (1999) Intercalated cell subtypes in connecting tubule and cortical collecting duct of rat and mouse. J Am Soc Nephrol 10:1-12

Kloth S, Gmeiner T, Aigner J, Jennings ML, Rockl W, Minuth WW (1998) Transitional stages in the development of the rabbit renal collecting duct. Differentiation 63:21-32

Loffing J, Le Hir M, Kaissling B (1995) Modulation of salt transport rate affects DNA synthesis in vivo in rat renal tubules. Kidney Int 47:1615-1623

Loffing J, Loffing-Cueni D, Hegyi I, Kaplan MR, Hebert SC, Le Hir M, Kaissling B (1996) Thiazide treatment of rats provokes apoptosis in distal tubule cells. Kidney Int 50:1180-1190

Loffing J, Vallon V, Loffing-Cueni D, Aregger F, Richter K, Pietri L, Bloch-Faure M, Hoenderop JG, Shull GE, Meneton P, Kaissling B (2004) Altered renal distal tubule structure and renal $\mathrm{Na}(+)$ and $\mathrm{Ca}(2+)$ handling in a mouse model for Gitelman's syndrome. J Am Soc Nephrol 15:2276-2288

Matsumoto T, Fejes-Toth G, Schwartz G (1996) Postnatal differentiation of rabbit collecting duct intercalated cells. Pediatr Res 39:1-12

Minuth WW, Gilbert P, Rudolph U, Spielman WS (1989) Successive histochemical differentiation steps during postnatal development of the collecting duct in rabbit kidney. Histochemistry 93:19-25
Na KY, Oh YK, Han JS, Joo KW, Lee JS, Earm JH, Knepper MA, Kim GH (2003) Upregulation of $\mathrm{Na}^{+}$transporter abundances in response to chronic thiazide or loop diuretic treatment in rats. Am J Physiol Renal Physiol 284:F133-F143

Norman JT, Bohman RE, Fischmann G, Bowen JW, McDonough A, Slamon D, Fine LG (1988) Patterns of mRNA expression during early cell growth differ in kidney epithelial cells destined to undergo compensatory hypertrophy versus regenerative hyperplasia. Proc Natl Acad Sci USA 85:6768-6772

Nouwen EJ, Verstrepen WA, Buyssens N, Zhu MQ, De Broe ME (1994) Hyperplasia, hypertrophy, and phenotypic alterations in the distal nephron after acute proximal tubular injury in the rat. Lab Invest 70:479-493

Quentin F, Chambrey R, Trinh-Trang-Tan MM, Fysekidis M, Cambillau M, Paillard M, Aronson PS, Eladari D (2004) The $\mathrm{Cl}^{-} / \mathrm{HCO}_{3}{ }^{-}$exchanger pendrin in the rat kidney is regulated in response to chronic alterations in chloride balance. Am J Physiol Renal Physiol 287:F1179-F1188

Royaux IE, Wall SM, Karniski LP, Everett LA, Suzuki K, Knepper MA, Green ED (2001) Pendrin, encoded by the Pendred syndrome gene, resides in the apical region of renal intercalated cells and mediates bicarbonate secretion. Proc Natl Acad Sci USA 98:4221-4226

Rubera I, Loffing J, Palmer LG, Frindt G, Fowler-Jaeger N, Sauter D, Carroll T, McMahon A, Hummler E, Rossier BC (2003) Collecting duct-specific gene inactivation of alphaE$\mathrm{NaC}$ in the mouse kidney does not impair sodium and potassium balance. J Clin Invest 112:554-565

Sabolic I, Katsura T, Verbavatz JM, Brown D (1995) The AQP2 water channel: effect of vasopressin treatment, microtubule disruption, and distribution in neonatal rats. J Membr Biol 143:165-175

Satlin LM, Schwartz GJ (1987) Postnatal maturation of rabbit renal collecting duct: intercalated cell function. Am J Physiol 253:F622-F635

Satlin LM, Matsumoto T, Schwartz GJ (1992) Postnatal maturation of rabbit renal collecting duct. III. Peanut lectin-binding intercalated cells. Am J Physiol 262:F199-F208

Schwartz GJ (2001) Plasticity of intercalated cell polarity: effect of metabolic acidosis. Nephron 87:304-313

Schwartz GJ, Tsuruoka S, Vijayakumar S, Petrovic S, Mian A, Al-Awqati Q (2002) Acid incubation reverses the polarity of intercalated cell transporters, an effect mediated by hensin. $\mathbf{J}$ Clin Invest 109:89-99

Shi SR, Key ME, Kalra KL (1991) Antigen retrieval in formalinfixed, paraffin-embedded tissues: an enhancement method for immunohistochemical staining based on microwave oven heating of tissue sections. J Histochem Cytochem 39:741-748

Stanton BA, Kaissling B (1988) Adaptation of distal tubule and collecting duct to increased $\mathrm{Na}$ delivery. II. $\mathrm{Na}^{+}$and $\mathrm{K}^{+}$transport. Am J Physiol 255:F1269-F1275

Teng-umnuay P, Verlander JW, Yuan W, Tisher CC, Madsen KM (1996) Identification of distinct subpopulations of intercalated cells in the mouse collecting duct. J Am Soc Nephrol 7:260-274

Tsuruoka S, Schwartz GJ (1996) Adaptation of rabbit cortical collecting duct $\mathrm{HCO}_{3}$ - transport to metabolic acidosis in vitro. $\mathrm{J}$ Clin Invest 97:1076-1084

van de Ven MJ, Colier WN, Oeseburg B, Folgering HT (1999) Induction of acute metabolic acid/base changes in humans. Clin Physiol 19:290-293

Verlander JW, Madsen KM, Cannon JK, Tisher CC (1994) Activation of acid-secreting intercalated cells in rabbit collecting duct with ammonium chloride loading. Am J Physiol 266:F633-F645 
Verlander JW, Hassell KA, Royaux IE, Glapion DM, Wang ME, Everett LA, Green ED, Wall SM (2003) Deoxycorticosterone upregulates PDS (Slc26a4) in mouse kidney: role of pendrin in mineralocorticoid-induced hypertension. Hypertension 42:356-362

Verrey F, Loffing J, Zecevic M, Heitzmann D, Staub O (2003) SGK1: aldosterone-induced relay of $\mathrm{Na}^{+}$transport regulation in distal kidney nephron cells. Cell Physiol Biochem $13: 21-28$

Vogetseder A, Karadeniz A, Kaissling B, Le Hir M (2005) Tubular cell proliferation in the healthy rat kidney. Histochem Cell Biol 124:97-104

Wagner CA, Finberg KE, Breton S, Marshansky V, Brown D, Geibel JP (2004) Renal vacuolar $\mathrm{H}^{+}$-ATPase. Physiol Rev 84:1263-1314
Wall SM, Hassell KA, Royaux IE, Green ED, Chang JY, Shipley GL, Verlander JW (2003) Localization of pendrin in mouse kidney. Am J Physiol Renal Physiol 284:F229-F241

Witzgall R, Brown D, Schwarz C, Bonventre JV (1994) Localization of proliferating cell nuclear antigen, vimentin, c-Fos, and clusterin in the post ischemic kidney. Evidence for a heterogenous genetic response among nephron segments, and a large pool of mitotically active and dedifferentiated cells. J Clin Invest 93:2175-2188

Yasoshima K, Satlin LM, Schwartz GJ (1992) Adaptation of rabbit cortical collecting duct to in vitro acid incubation. Am J Physiol 263:F749-F756 